\title{
Travel and Writing in the Period of 'High Imperialism': Hajj Pilgrimage Narratives by the Begums of Bhopal
}

\author{
Shafana Shaffi \\ Assistant Professor, Department of English, T.K.M. College of Arts and Science, Kollam, \\ Kerala. ORCID: oooo-ooo1-9337-1449. Email: shafanashaffin@gmail.com
}

\begin{abstract}
This paper aims to study narratives by two Indian Muslim women - the formidable Begums of Bhopal who travelled to Mecca for pilgrimage in the latter half of the nineteenth and the early decade of the twentieth century. It attempts to trace the notions of imperialism and femininity that guide the women narrators and study as to how these personal narratives fit into the larger framework of colonial enterprise without intending to do so. Also by adopting a unique style that was at once in compliance with power structures like imperialism but that which resisted others like patriarchy, the Begums' succeeded in fashioning their narratives as a powerful tool to portray their selves as faithful subjects of the Raj and who were also the rightful rulers of Bhopal. The texts, by bearing in mind the intended audience and the expected reception, are as much the products of the time as they are of the author's personal intentions.
\end{abstract}

Keywords: travel, pilgrimage narratives, colonialism, Western male narratives, femininity, Other

\section{Introduction}

I begin with L. K. Worley's assertion that "very few women broke out of the domestic circle in the nineteenth century to venture into the wider world as self-acknowledged travellers" (1986, p.40). Worley's claim was furthered by Floriane Reviron whose study on Isabella Bird observed that when a woman of late nineteenth century decided to write a travelogue, it was not just the genre that was at stake but also her gender, for with her writing she vied “for recognition as man's equal" and "to reassert her femininity" (2009, p.72). But is it right to term every travel narrative by women, written during the period of "high imperialism" (Morris, 1979, p. 23), especially by women of the East, as a strong plea for recognition and approval? If it indeed followed 'the pattern', what was the role played by the colonial enterprise in shaping the narrative? This paper aims to study narratives by two Indian Muslim women - the formidable Begums of Bhopal - who travelled to Mecca for pilgrimage in the latter half of the nineteenth and the early decade of the twentieth century. Hajj pilgrimage to Mecca, the fifth of the five pillars of Islam, is mandatory to all Muslims with health and means, making the journey and the performance of the rituals sanctioned by and even revered across geographical borders and times. Nawab Sikander Begum's A Pilgrimage to Mecca (1870 [English translation]) and Nawab Sultan Jahan Begam's The Story of a Pilgrimage to Hijaz (1909), are not merely about the 'experiences of female pilgrims'; the narratives ought to be at once viewed as travelogues and as life stories that are to be read in relation to the historical and socio-political changes that they were subject to. And while doing so, the paper will enquire into the politics of colonialism, gender, Muslim identity, and the subtle but careful construction of the self that the narratives entail.

(C) AesthetixMS 2020. This Open Access article is published under a Creative Commons Attribution Non-Commercial 4.o International License (http://creativecommons.org/licenses/by-nc/4.o/), which permits non-commercial re-use, distribution, and reproduction in any medium, provided the original work is properly cited. For citation use the DOI. For commercial re-use, please contact editor@rupkatha.com. 


\section{Imperialism and its Impact on Hajj}

Islamic scholars and statesmen like David Margoliouth and Sir Richard Temple, along with Indian scholars like Cherag Ali and Faisal Devji have claimed that the British Empire was, during the period of 'high imperialism', the greatest Muslim power in the world with the larger interests of their Muslim subjects playing a vital role in formulating British policies (Slight, 2015, p. 1). And ironically, "in global terms, the British empire's first religion was Islam" (Slight, 2015, p. 2) as the empire's territories extended as far as Nigeria, Egypt, Palestine, India, Malaya, Trans-Jordan etc. among others. Simply put, any significant curb imposed on the transcontinental, obligatory pilgrimage of Muslims would have led to widespread unrest and even rebellion. However, it is not that the practice of pilgrimage was encouraged or that much was done to facilitate a safe passage to and from Mecca for the economically weaker sections of the society. The dilemma that the Empire faced with respect to Indian scenario was the difficult "choice between non-interference and the necessity to control" (Mishra, 2011, p. 16) as the number of Indian pilgrims journeying to Mecca was very high. Cholera outbreaks and the massive spread of the disease during the period of Hajj was a public health issue, and it gave the colonial masters their first real chance to regulate the pilgrim flow.

When British Empire came up with regulations on pilgrim ships and instituted compulsory medical check-ups for pilgrims, the Ottoman Empire that controlled the Arabian Peninsula and hence the Hajj pilgrimage till 1918, came up with their own set of restrictions. In 1882, Constantinople's Superior Council of Health passed a decision that "all pilgrim vessels from Bombay bound for Jeddah were obliged to call at the island of Kamaran in the Red Sea, about 500 miles south of Jeddah" (Mishra, 2011, p. 16). Kamaran was the island chosen by the Ottomans to quarantine the pilgrims from South or South-East Asia for a period of 15 days, during which they were tested for infection. This precedence gave the British a chance to demand medical examination and inoculation of pilgrims, failing which they were denied the Bill of Health that sanctioned their travel. In spite of such elaborate regulations, the state of ships ferrying the pilgrims were deplorable. The reality remained that such impositions only affected the poor and uneducated pilgrims, the very crowd that the empire did not want on board due to the fear of religious fanaticism and disease outbreak. The popular narrative, however, was that the "poor pilgrims had to be protected from themselves as they lacked the capacity to recognise the difficulties of the journey" and that any effort to do so by the government would backfire "as (poor) pilgrims would fail to see the benevolent intentions of the Raj" (Mishra, 2011, pp.20-21, emphasis added). The same thought was first voiced in Radhika Singha's work on 'pauper' pilgrims wherein she states that the British officials in India deemed poor pilgrims as "ignorant rustics, lured out by wily guides, with no idea about what lay ahead and with no forethought about the means of return" (2008, p. 54).

\section{The Begums of Bhopal and the British Empire}

The treatment meted out to the poor was, however, not what was extended to the rich and favoured, as can be understood from the narratives of the Begums of Bhopal. On the contrary, administerial help was provided to the Nawabs, with English doctors deputed to escort the Begums till Jeddah and letters of recommendation from the Governor of Bombay to facilitate customs clearance. Nawab Sikander Begum's journey began in November 1863 with a retinue of 1500 people, maids and cooks included, and a special train was arranged to take her caravan to Bombay from where they set sail in three ships chartered for the purpose (Khan, 2004, pp. 108109). As for Nawab Sultan Jahan's pilgrimage, it was noted by biographers that: 
... the preparation and strategy took the form of a vast, minutely planned military campaign. Given her meticulous attention to detail, Sultan Jahan first sent a volley of letters and telegrams to the British government, seeking their help in chartering a ship and arranging accommodation, protocol, quarantine, stores and medical attendants. She wrote to the Ottoman Emperor, Sultan Abdul Hamid of Turkey, informing him of her impending pilgrimage and received a most courteous reply (Khan, 2004, p. 161).

She, however, travelled to Mecca in 1903 with a retinue of 300 persons, one-fifth the number that her grandmother had taken. Her ship was placed in quarantine for a mere five days, with her crew staying on board, and the Sultan of Turkey ordering a contingent of 700 Turkish troops to escort and ensure safety to Nawab Sultan Jahan's caravan. With so much support flowing in from the Empire, it is interesting to note as to how the colonial enterprise influenced the narrative.

But before taking into consideration the narratives, it is essential to present a brief historical background in order to have a better idea about the narrators focused on in this paper. In 1819, a then eighteen-year old Qudsia Begum became the ruler of Bhopal, a major princely state in British India. Having been widowed, the British political agent appoints Qudsia as regent of Bhopal until her daughter, Sikander Begum reaches of age and marries and re-establishes the 'man's rule'. However, it was the beginning of four generations of women's rule in Bhopal which was constantly put to test by both the men in their lives and by the Raj. At every step, the Begums had to prove their mettle and wield the power under the persistent threat of losing their land and throne. Sikander Begum proved to be a very competent ruler and by quelling the rising protests in Bhopal during the 'Sepoy Mutiny' of 1857, she garnered the praise of the British Empire. She also brought in significant administrative reforms and was far sighted in her governance. Her term was so impressive that "the British withdrew their proviso that the husband of the Begum would become the Nawab, naming Shah Jahan Begum (Sikander's daughter) as sovereign in her own right upon the death of Sikander in 1867" (Hurley, 1998, p. 264). Shah Jahan was succeeded by Sultan Jahan Begum in 1901 and she ruled as the last female sovereign of Bhopal for twenty-five years. Having been influenced by her grandmother, Sultan Jahan focused her attention on promoting education among girls and women. She journeyed to Mecca for Hajj in 1903 and returned in 1904, and on her return proceeded to establish educational institutions, especially for women, and also introduced the system of ladies' prayer rooms in mosques. "By 1907, Bhopal city boasted five state-sponsored girls' schools, catering to the needs of elite Hindus and Muslims, as well as widows, orphans, and other poor girls" (Hurley, 1998, p. 265). History stands witness to the fact that both the Begums of Bhopal who journeyed to Mecca for Hajj were skilled diplomats and shrewd rulers. It is this foresight and diplomacy that shapes their narratives and when travelogues by Western women in the mid-Victorian era were seen as mediums to 'reassert the narrator's femininity', the select narratives worked as mediums to assert the authority and reign of Sikander Begum and Sultan Jahan Begam.

Regarding the same, it is important to note that the pilgrimage narrative by Nawab Sikander Begum was not intended for publication or a wider readership. It was "written in $1867 \ldots$ in compliance with a request from Lady Durand, whose husband, Sir H.M. Durand, had formerly been Political Agent at the Begum's Court" (Begum, 1870 [2007], translator's preface to the narrative, emphasis added). The narrative was originally written in Urdu and was dedicated to "Her Majesty Queen Victoria" and two copies were all that was prepared; one for Lady Durand and one for the then Political Agent in Bhopal, Lt.Col. Willoughby-Osborne. The work was then translated to English by Mrs. Willoughby-Osborne and published in 1870, two years after the death of Sikander Begum. A reference to this request made by Lady Durand, cited in the first 
chapter of the narrative, reads thus: "if ever your Highness writes a description of your pilgrimage, I shall be delighted to see it" (Begum, 1870 [2007], p. 1). The letter adds that Colonel Durand "was anxious to hear what my (her) impressions of Arabia generally, and of Mecca in particular, might be" (Begum, 1870 [2007], p. 2, emphasis added). This request is particularly important as Richard Burton's pilgrimage narrative, published in 1855, had given the European readers, what Pratt describes as, "a sense of ownership, entitlement and familiarity" (Pratt, 2008, p. 3) of a place like Mecca that was barred to non-Muslims. Hence Colonel Durand's anxiousness seems to come from his thirst for information and validation of the Western narratives on Hijaz. Although the narrative of Sikander Begum was prompted by such requests and though it aligned itself with the colonial enterprise - with praise lavished upon the British Empire - she fashioned the narrative as a powerful tool to portray herself as a faithful subject of the Raj, an able ruler and 'the right choice' for Bhopal. Her writing, therefore, can be seen as her resistance to the then patriarchal notions that deemed women unfit to be rulers and law makers of the land.

\section{Uniqueness of the Narratives}

As for the style of the narratives, it is important to note that the Begums of Bhopal adopted a unique style that was at once in compliance with power structures like imperialism but that which resisted others like patriarchy. In this regard, the observation by Frigga Haug holds true, for the narratives do not pan out merely as a "bundle of reactions to all-powerful structures, or to the social relations within which we (the narrators) have been formed"; in fact, the narratives, as the sociologist states, comes across as "possible indications" of how the Begums "participated actively" in shaping their "own past experience" (Haug, 1987, p. 35) and ensuring a noninterference to their rule in future. To further this observation, it is vital to note that the narratives by the two Begums stand in stark contrast to the earlier form of self narratives by the Indian rulers. For instance, it is greatly different from the 'namas' written during the sixteenth and seventeenth century by the Mughal emperors. When the 'namas' attempted at perpetuating the farr-i izzadi notions, "the divinely ordained 'flame' of kingship" (Bokhari, 2015, p. 168), the narratives explicate the constant struggle of the Begums to prove themselves as strong and worthy rulers of the land. One comes across in the works, a strong authoritarian narrative voice and a conscious non-compliance with the discourses of femininity that was in vogue in the West during the late nineteenth and early twentieth centuries.

Hence, when the travel writings by Western women of the age were regarded to be "more tentative than the male writing" (Mills, 1991, p. 3) because of their adherence to the notions of femininity, the Begums of Bhopal used the tried and tested methods of documentation and erasure of the personal to ensure that their narratives were regarded seriously. Though the Begums' narratives of Hajj pilgrimage differ greatly from the narratives written by the likes of Burton and Charles Doughty, there were common grounds with regard to the extensive documentation of the place, climate, town planning, administrative flaws etc. and the description of the Other. This paper, therefore, puts forward the idea that it is in fact the pressure of dominant discourses of the time and the female travel narrator's compliance or resistance to it that shapes her travel writing. Unlike the 'poor pilgrims', women included, who did not have the means or agency to get their voice heard, or the Western woman who were bound by the invisible bonds of Victorian morality, the aristocratic Begums willed their narrative to construct the image of the formidable rulers that they were.

Cheryl McEwan, while talking about the variations in style in Victorian women travellers

writes that one major reason for the fluctuating style is that, "travel writing by white women were 
positioned geographically, metaphorically and metaphysically between the dominant culture and the 'wild zone'. While both men and women have occupied these margins in literary production, they have been positioned there in very different ways" (McEwan, 200o, p.9, emphasis added). While reading Hajj pilgrimage narratives written between mid-nineteenth century and early twentieth century, by both Western male explorers and ethnographers and by the Begums of Bhopal, one comes across a stark contrast in their approach to the 'travel destination'. It was for the Westerners, like Richard Francis Burton, a 'wild zone'; getting there by risking their lives was taken as a challenge, a gratification of pride. In his Personal Narrative of a Pilgrimage to AlMadinah and Meccah, he writes that the pilgrimage to Mecca was performed by Muslims in a "fit of religious enthusiasm, likest to insanity" and that "this emigration is fraught with evils. It sends forth a horde of malcontents that ripen into bigots; it teaches foreign nations to despise our rule; and it unveils the present nakedness of once wealthy India" (Burton, 1855, pp. 184-185). However, in the narrative of Nawab Sultan Jahan Begam, she writes: "from my earliest childhood I had longed to pay a visit to this holy sanctuary" (Begam, 1909, p. 9, emphasis added) and that "the Hajj is the best means of making Musalmans realise that all are equal" (Begam, 1909, p. 6). So, when for the prying Western traveller Mecca is the peripherally positioned 'wild zone', it is for the Muslim believer 'the center out there'. When Colonel Durand was anxious to hear about Sikander Begum's impressions of Mecca, he seems to have been looking for either validation or contestation of the well-received views of Richard Burton. But the diplomatic ruler that Begum was, she employed a narrative style as closely similar to Burton's as possible.

It is interesting to note how Sikander Begum's narration of the city of Mecca, its people, the Bedouins, the Ottoman control of the holy lands of Mecca and Medina and the attitudes of the Sherif and Pasha (Governor) of Jeddah as well as that of Mecca is in accordance with her allegiance to and alignment with the British Empire. As Susan Basnett puts it, there is a collusion with, albeit unconsciously, "the colonial enterprise" (Basnett, 2012, p. 228). The narrative is so framed that the Turks are portrayed as ineffectual guardians of the holy land whose apparent neglect has left the cities of Jeddah and Mecca in shambles. Begum writes: "Jeddah is a town on the sea shore...from a distance (it) has an imposing appearance. On entering the city, however, one is struck by the dirty aspects of the streets and their total want of drainage" (Begum, 1870 [2007], p. 27). Her work is carefully curated to appeal to her intended audience and it is predominantly about the life at Mecca and the flaws of the Turkish rule. When in the translator's preface Mrs. Willoughby-Osborne writes how the translation will provide the general reader "the opportunity of viewing things from an Oriental point of view" (Begum, 1870 [2007], translator's preface) and remarks on the novelty attached to it, little did she know that the Begum's narrative will come across as an extension of the colonial narrative with her choice of generalised statements and metaphors. Sikander Begum of Bhopal had "internalised the British ideals of an 'improving' ruler" (Metcalf, 1990, p. 90) so much so that she suggests the improvements she could have brought about in Mecca had she been in charge of the city. She even makes it a point to write everything that she had mentioned to the Pasha so that her intended readers will have an idea as to how fearless, headstrong and pro-reformative a ruler she is (and hence the right choice for Bhopal in the years to follow). After having been repulsed by the habits of the people at Mecca and by the dismal condition of their houses in general and city in particular, Begum remarks to the Pasha of Mecca:

The Sultan of Turkey gives thirty lakhs of rupees a year for the expenses incurred in keeping up the holy places at Mecca and Medina. But there is neither cleanliness in the city, nor are there any good arrangements made within the precincts of the shrines. Now if the Sultan would give me those thirty lakhs, I would make arrangements for the 
Government of Bhopal to be carried on by my son-in-law and daughter, and you would see what a state of order and cleanliness $I$ would keep the august cities in, and what arrangements $I$ would make for the proper maintenance of the holy shrines; so that the Sultan would find out that dishonest people had been diverting his money from its legitimate uses, and had not kept a single thing in order; while I, in a few days, would effect a complete reformation! (Begum, 1870 [2007], p. 128, emphasis original)

It is therefore worth noting as to how deeply her narrative was entwined with the colonial enterprise though she, instead of being a part of the colonial expansion, was only a subject of it. And it would even be right to say that with her narrative she was putting herself out as a loyal subject of the Crown who will forever forward the cause of British imperialism. The narrative is hence her response to the colonial discourse and how well she complies with it. As for the style of the narrative, the personal is more or less effaced and importance is given to detailed documentation. Unlike the many Western male travellers like Burckhardt and Doughty, who packed their narrative with ethnographic details, Nawab Sikander Begum presents her eye for details in matters of governance and administration. The narrative style employed is therefore 'unwomanly' as per Victorian standards, but it made it more authentic and agreeable to her intended readers.

As for the narrative of Sultan Jahan Begam, it is divided into two books, wherein the first book has a detailed geographical description of Arabia, including that of the mosques and tombs of importance, and the second book has the events and incidents related to her pilgrimage. When compared to her grandmother's narrative, her narrative tone is more mellowed. Though she elaborates on the progressive administrative measures that she has employed as the ruler of Bhopal and describes the "arduous responsibilities of the State" (Begam, 1909, p. 9), it is evident that the demand for a male rule and the pressures of patriarchy was much lesser than that it was at Sikander's time. Sultan Jahan portrays herself as an efficient ruler and as someone who places her duty over and above every personal wish of hers. She writes that when she succeeded her mother as the ruler of Bhopal, "the State ... resembled a tottering pillar and the condition of helplessness to which it had been reduced haunted me day and night (Begam, 1909, pp. 9-10) and then goes forth to describe the changes brought about by her. Her narrative also holds long accounts of how she has delegated duties to her son and the ministers to run the affairs of the state in her absence. Unlike Sikander Begum's narrative that had to win the favour of the British audience, Sultan Jahan's narrative is more sated, with importance given to the explication of her policies and plans for furthering the cause of education, especially women's education.

\section{The Other as opposed to the Self}

The narratives by the Begums of Bhopal, though did not get the academic attention it deserved, is multi layered and complex in that it subtly constructs a self that stands in stark contrast to the 'Other' in Arabia - the 'Other Muslim, the 'Other' Women, the 'Other' Orient. While writing of the people at Jeddah, Sikander Begum, comments that "every native of India who lands at Jeddah has a dollar or half dollar, according to his condition in life, extorted from him" (Begum, 1870 [2007], p. 29). By stating that the Arabians in general are greedy and money grabbing, she hints that they are being led by bad example by their Turkish Sherif and Pasha, and that in contrast to this, the Indians are better off as they are under the exemplary rule of the British. In this regard, her narrative is closely akin to that of Richard Burton who believed that the people of Arabia yearned for Western rule, and wished it with all their might. It is interesting to note that Begum's narrative published a decade after Burton's, reflects the same colonial undertones and it can be 
concluded that such views were in vogue back in the late nineteenth century. The narrative strikes a similar chord with the accounts by male European writers and reporters while describing Mecca. Begum notes that the sanitary arrangements of the city are bad and that the streets are "dirty and ill-drained" (Begum, 1870 [2007], p. 68). She recapitulates her views on Mecca in Chapter XVIII and writes that the city is "desolate looking", "dirty" and "pervaded with unsavoury odours", that water is scarce and whatever little available is "dirty... with great many insects on it" (Begum, 1870 [2007], p. 129). With regard to the people, she writes: "the Turks are very dirty in their habits and gross livers; I do not know whether they are well set up or not when in uniform or at drill, but in their houses, they are very dirty and untidy" (Begum, 1870 [2007], p. 69). Her narration about Mecca is very similar to the reports that surfaced on Western newspapers and journals of late nineteenth century. Bleak pictures of a filth ridden city often came up and these narratives gave rise to the likes that was published in London Society in 1886 which described that "the confections (in the Mecca bazaar) were covered with fierce clouds of pugnacious hornets ... (and) black masses of flies that shared with them the spoil. Greasy looking Moslems lounged and squatted by the sides of their stalls, all smoking hookahs as if it were the business of their lives" (cited in Mishra, 2010, p. 84). It is to be noted that Sikander Begum's account was very much in line with the general perception of Mecca prevalent at that time.

As of the people, Sikander Begum adds that "there is no kindness of disposition among the inhabitants, but they are characterised by a large amount of cruelty and oppression. They consider it a meritorious act to oppress the natives of India - just as a heretic considers it a meritorious act to persecute the true believer" (Begum, 1870 [2007], p. 29). By drawing the metaphor, she quickly takes the position of a victim who is being cheated of her money and possessions as the 'other' is inconsiderate of even her status of being a pilgrim. Begum proceeds to say that the "manners of these people resemble those of the Gonds in India of former days, who were rough mountaineers that lived by rapine and deeds of violence" (Begum, 1870 [2007], p. 30). The Westerners notion of the barbaric hordes of the East gets reinstated with this allusion and the narrative seems to say that if not for the coloniser, Indians would have remained like the Gonds of the former days or would have been closely akin to the Arabians that Sikander Begum comes across. By portraying herself as very different from the 'other' in Arabia, and by depicting herself as a loyal subject of the Raj, her narrative functions as a medium that justifies and, in ways, sanctifies the colonial enterprise.

It is quite surprising that The Begums, in spite of being colonial subjects themselves, regard the people of the East, especially women, with prejudice. Along with the Oriental gaze on the land, Sikander Begum regards the women of the land and presents them as being fickle minded and morally lose:

Women frequently contract as many as ten marriages, and those who have only been married twice are few in number. If a woman sees her husband growing old, or if she happens to admire anyone else, she goes to the Sherif, and after having settled the matter with him, she puts away her husband, and takes to herself another, who is perhaps young, good-looking, and rich. In this way a marriage seldom lasts more than a year or two. (Begum, 1870 [2007], p. 72)

This description is however in loggerheads with the usual narration of Arab women being subjugated and oppressed and having to live a cloistered life.

So even when the "dominant reading" of the Begums' texts are not autobiographical per say, when compared to the women's travel writing from the West, their texts present an 
alternative angle to the "common-sense assumptions about femininity which circulated at the time" (Mills, 1991, p. 51). We are to understand that the nuances of production and reception of the texts played a huge role in the selection of experience that went into the narratives. More importantly, the narratives of the formidable Begums of Bhopal present a frame that contradict with the otherwise given notions of Muslim women from the East who are usually depicted as oppressed, muted beings who are invisible behind their veils.

\section{Notes}

'The phrase is inspired by the title of Victor Turner's 1973 article titled “The Center Out There: Pilgrim's Goal" published in History of Religions.

\section{References}

Basnett, Susan (2012). Travel Writing and Gender. In Peter Hulme and Tim Youngs (Eds.), The Cambridge Companion to Travel Writing. Cambridge: Cambridge University Press, 225-241.

Begam, Nawab Sultan Jahan (1909). The Story of a Pilgrimage to Hijaz. Calcutta: Thacker, Spink \& Co.

Begum, Nawab Sikander (1870 [2007]). A Pilgrimage to Mecca. In Siobhan Lambert Hurley (Ed.), A Princess's Pilgrimage: Nawab Sikander Begum's A Pilgrimage to Mecca. New Delhi: Women Unlimited.

Bokhari, Afshan (2015). Masculine Modes of Female Subjectivity. In Anshu Malhotra and Siobhan Lambert Hurley (Eds.), Speaking of the Self: Gender, Performance and Autobiography in South Asia. New Delhi: Zubaan, 165-202.

Burton, Richard Francis (1855). Personal Narrative of a Pilgrimage to al-Medina and Meccah, Vol II. London: G. Bell and Sons.

Haug, Frigga et al. (1987). Female Sexualization: A Collective Work of Memory. London: Verso.

Hurley, Siobhan Lambert (1998, May). Out of India: The Journeys of the Begam of Bhopal, 1901-1930. In Women's Studies International Forum (Vol. 21, No. 3, pp. 263-276). Pergamon.

Khan, Shaharyar M. (2004). The Begums of Bhopal: A Dynasty of Women Rulers in Raj India. New Delhi: Viva Books.

McEwan, Cheryl (2000). Gender, Geography and Empire: Victorian Women Travellers in East Africa. Aldershot: Ashgate.

Metcalf, Barbara D (1990). The Pilgrimage Remembered: South Asian Accounts of the hajj. In Dale F. Eickelman and James Piscatori (Eds.), Muslim Travellers: Pilgrimage, Migration, and the Religious Imagination. Berkeley and Los Angeles: University of California Press, 85-107.

Mills, Sara (1991). Discourses of Difference: An Analysis of Women's Travel Writing and Colonialism. London: Routledge.

Mishra, Saurabh (2010). Pilgrimage, Politics, and Pestilence: The Haj from the Indian Subcontinent, 186o1920. New Delhi: Oxford University Press.

Morris, James (1979). Pax Britannica: The Climax of an Empire. Harmondsworth: Penguin.

Pratt, Mary Louise (2008). Imperial Eyes: Travel Writing and Transculturation. New York: Routledge. 
Reviron, Floriane (2009). Isabella Bird's in Japan: Unbeaten Tracks in Travel Literature. In Beatrice Bijon and Gerard Gacon (Eds.), In-Between Two Worlds: Narratives by Female Explorers and Travellers 18501945. New York: Peter Lang Publishing, 67-80.

Singha, Radhika (2008). Passport, Ticket, and India-Rubber Stamp: 'The Problem of the Pauper Pilgrim 'in Colonial India c. 1882-1925. In Aswini Tambe and Harald Fischer-Tine (Eds.), The Limits of British Colonial Control in South Asia: Spaces of Disorder in the Indian Ocean Region. New York: Routledge. 4983.

Slight, John (2015). The British Empire and the Hajj 1865-1956. Cambridge: Harvard University Press.

Worley, L.K. (1986) 'Through Others' Eyes': Narratives of German Women Travelling in Nineteenth Century America. Yearbook of German-American Studies, 21, 39-50.

Shafana Shaffi is an Assistant Professor at the Department of English, T.K.M. College of Arts and Science, Kollam, Kerala and is pursuing a doctoral degree in English and Cultural Studies from Centre for English Studies (CES), JNU. 